\title{
OPTIMASI BENTUK RANGKA ATAP STRUKTUR KUDA-KUDA BAJA CANAI DINGIN
}

\author{
Irfan Adhe Mashudi \\ Edi Santoso, Nindyawati
}

\begin{abstract}
Abstrak: Pertumbuhan atau kenaikan penduduk Indonesia yang sangat pesat mengakibatkan bertambahnya jumlah kebutuhan rumah tinggal yang juga semakin meningkat. Saat ini pembangunan seperti apartemen, dan perumahan sangat banyak didaerah perkotaan yang diakibatkan karena bertambahnya penduduk, atau migrasi dari desa ke perkotaan untuk mengimbangi dari pertumbuhan penduduknya. Rumah - rumah yang dibangun di perumahan pada umumnya banyak yang menggunakan rangka baja ringan sebagai atapnya. Material rangka atap biasanya dari kayu, beton, baja dan baja ringan, masing-masing memilik kelebihan dan kekurangannya. Dalam hal ini material kuda-kuda baja ringan mempunyai banyak kelebihan dibandingkan dengan material yang lainnya dalam penelitian-penelitian yang dilakukan sebelumya. Beberapa tipe rangka untuk baja canai dingin antara lain tipe Howe, Pratt, Fan, Fink, Scissors dll. Untuk itu perlu dilakukan optimasi dari bentuk-bentuk rangka kuda-kuda baja ringan, untuk mencari bentuk rangka yang optimum, aman, ekonomis dan efisien. Penelitian ini bertujuan untuk mendapatkan bentuk optimum maksimal dari rangka kuda-kuda baja ringan, megetahui beban maksimal, lendutan maksimal pada konfigurasi rangka, angka keamanan dan pola keruntuhan dari rangka kuda-kuda baja ringan akibat beban statis, sehingga bisa dijadikan sebagai rujukan untuk diterapkan pada jenis-jenis rangka kuda-kuda baja ringan yang lain. Dari penelitian ini didapatkan hasil berdasarkan pemodelan secara analitis dari beberapa tahap bentuk dari rangka kuda-kuda baja canai yang ditemukan, yakni bentuk rangka Fink yang dimodifikasi dengan batang horizontal dengan tipe $\mathrm{F} 1$ pada proses modifikasi. Pada tahap selanjutnya yakni proses kombinasi rangka tidak mencapai bentuk yang optimum. Lendutan maksimum pada pemodelan secara analitis yakni sebesar $11.17 \mathrm{~mm}$ pada beban $2250 \mathrm{~kg}$. Sedangkan pada pemodelan prototipe lendutan maksimum yang terjadi sebesar $11.33 \mathrm{~mm}$ pada beban $1270.99 \mathrm{~kg}$ dan didapatkan hasil angka keamanan yang direkomendasikan sebesar 1,4. Untuk pola keruntuhan keruntuhan yang terjadi, pada $1 / 2,1 / 4$ bentang terjadi tekuk torsi, dan pada bagian tumpuan terjadi tekuk lentur torsional.
\end{abstract}

Kata-kata kunci: Baja Canai dingin, Rangka Atap, Kuda-Kuda, Bentuk Rangka Optimum.

Abstract:The growth or increase in Indonesia's population is very rapid resulting in the increasing number of residential needs which are also increasing. At present development such as apartments and housing is very much in the urban areas due to increasing population, or migration from rural to urban areas to compensate for population growth. Many houses built in housing use light steel frames as roofs. Roof truss material is usually made of wood, concrete, steel and mild steel, each of which has advantages and disadvantages. In this case the material mild steel easel has many advantages compared to other materials in previous studies. Several types of frames for cold rolled steel include Howe, Pratt, Fan, Fink, Scissors etc. For this reason, it is necessary to optimize the forms of lightweight steel truss, to find the optimum, safe, economical and efficient frame form. This study aims to obtain the maximum optimum form of light steel frame trestle, to know the maximum load, maximum deflection in frame configuration, safety figures and the collapse pattern of light steel frame truss due to static load, so that it can be used as a reference to be applied to other types of light steel frame truss. From this study the results obtained are based on analytical modeling of several stages of the shape of the form of rolled steel horses which are found, namely the shape of the Fink frame modified with horizontal rods with type F1 in the modification process. In the next step, the process of combining skeletons does not reach optimum shape. The maximum deflection in analytical modeling is $11.17 \mathrm{~mm}$ at a load of $2250 \mathrm{~kg}$. Whereas the maximum deflection modeling that occurred was $11.33 \mathrm{~mm}$ at a load of $1270.99 \mathrm{~kg}$ and the recommended safety figure was 1.4. For the pattern of collapse that occurs, at 1/2, 1/4 the span of the torsion bend occurs, and in the pedestal the bending torsional bending occurs.

Keywords: Cold Rolled Steel, Roof Truss, Easel, Optimum Frame Shape

Irfan Adhe Mashudi adalah Alumni Jurusan Teknik Sipil Fakultas Teknik UM; E-mail: irfanadhe65@gmail. com; Edi Santoso dan Nindyawati adalah Dosen Jurusan Teknik Sipil Fakultas Teknik Universitas Negeri Malang; Jalan Semarang No.5 Malang 65145; E-mail: edi.santoso..ft@um.ac.id dan nindyawati.ft@um.ac.id 
PENDAHULUAN

Struktur atap adalah bagian dari suatu bangunan yang berfungsi untuk menerima beban oleh berat sendiri yaitu beban kuda-kuda, gording reng, dan penutup atap yang kemudian diteruskan ke balok atau kolom sampai pondasi, juga berungsi sebagai penahan tekanan angin muatan yang berarah horizontal pada batang. (Herman, dkk; 2018). Konstruksi rangka atap (kuda-kuda) merupakan bagian atas dari suatu bangunan yang merupakan struktur batang yang diletakkan pada sebuah bidang dan saling dihubungkan dengan sendi pada ujungnya, sehingga membentuk suatu bagian bangunan yang terdiri dari segitiga (Rahayu dan Manalu, 2015). Kuda-kuda mempunyai bermacam-macam jenis bahan yaitu dari kayu, beton, baja konvensional dan baja canai dingin. (Ariz, 2015). Baja ringan atau baja canai dingin merupakan baja yang dibentuk tanpa peleburan tetapi dengan penggabungan atau penekanan lembaran baja tipis menjadi penampang yang dibutuhkan. (Sandjaya, 2018)

Menurut Rahayu dan Manalu (2015) dari segi mutu baja ringan mempunyai kuat tarik yang lebih besar dari pada kayu, baja ringan mempunyai mutu yang baik, juga dalam segi biaya pemasangan rangka atap baja ringan lebih murah dan dari segi waktu pemasangan rangka atap baja ringan lebih cepat dibadingkan dengan kuda-kuda kayu. Oktarina dan Dermawaan (2015) membandingkan berat struktur rangka atap baja ringan lebih ringan dibandingkan struktur rangka atap kayu. Oleh karena itu, saat ini banyak rumah yang dibangun menggunakan rangka atap baja ringan.
Rangka kuda-kuda baja ringan mempunyai beberapa tipe antara lain tipe Howe, Pratt, Fan, Fink, Scissors dll. Menurut Alpaine (2010), konfigurasi kuda-kuda pada umumnya digunakan berdasarkan panjang bentang kuda-kuda dan kebutuhan. Antara lain konfigurasi kuda-kuda Fink, Howe, scissors, fan, Cremona. Bentang yang digunakan pada masing-masing tipe kuda-kuda relatif, yaitu untuk bentang pendek, menengah dan bentang panjang. Untuk itu perlu dilakukan optimasi dari bentuk-bentuk rangka kuda-kuda baja ringan, dengan tujuan untuk mencari bentuk rangka yang optimum, ekonomis dan efisien dengan berat sendiri dari struktur rangka kuda-kuda.

\section{METODE}

Pemodelan analisis dilakukan dengan 3 tahap. Tahap pertama adalah pemodelan untuk mencari bentuk rangka optimum dengan rasio terkecil dari bentuk dasar dari rangka atap kuda-kuda yaitu rangka Pratt, rangka Howe, Rangka fan, Rangka Fink. Tahap kedua adalah memodifikasi rangka umum dan tahap terakhir adalah kombinasi bentuk rangka dengan ketentuan yang sudah ditentukan, dengan mencari nilai rasio terkecil. Permodelan prototipe kuda-kuda ini dimodelkan dan disesuaikan semirip mungkin dengan permodelan analisis yang sudah direncanakan. Rekomendasi angka keamanan menggunakan persamaan menurut Cheatam (1995) seperti persamaan 1 di bawah ini : $M s=1+\frac{\text { SelisihMaksimal }}{100 \%} \ldots . . .($ Persamaan 1$)$

Alur penelitian dapat dilihat pada Gambar 1 sebagai berikut: 


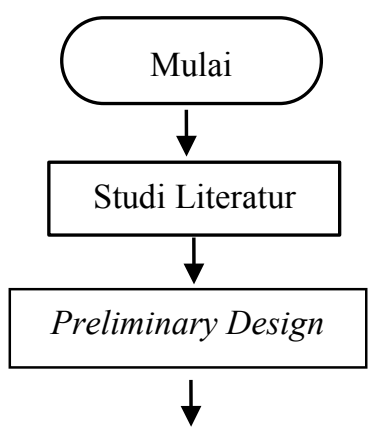

Pencarian bentuk optimum kuda-kuda secara analisis berdasarkan kombinasi 4 rangka umum :

- Pratt Truss - Howe Truss

- Fan Truss - Fink Truss

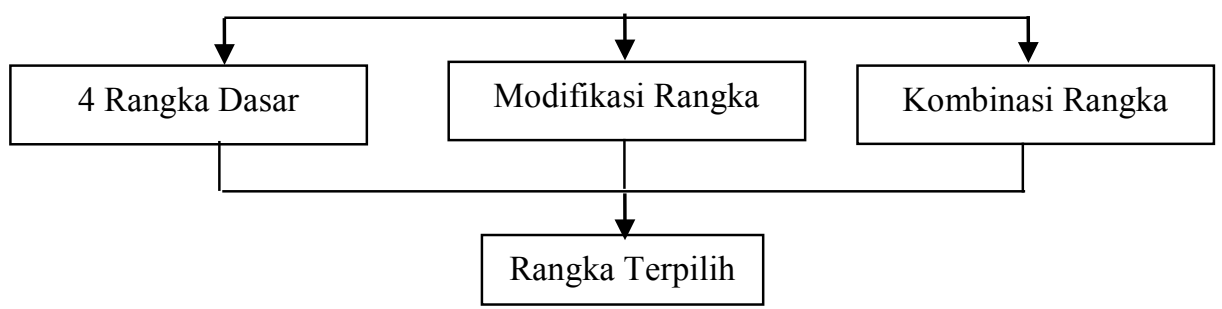

Pembuatan Kuda-Kuda Prototipe

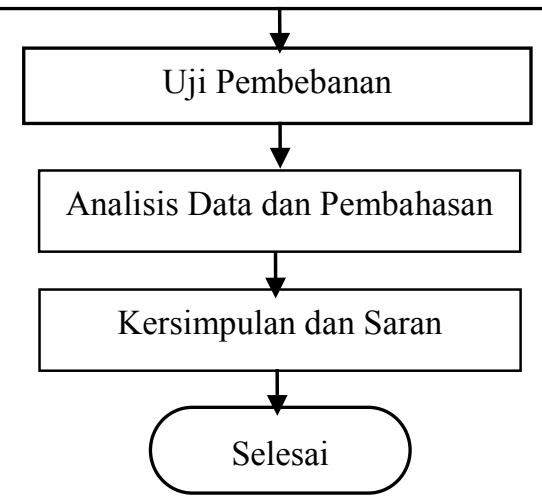

\section{Gambar 1. Alur Penelitian}

HASIL

1. Hasil Optimasi Analisis Rangka KudaKuda

\subsection{Hasil Analisis 4 Rangka Umum}

Pemodelan pada tahap ini yaitu dengan Analisis pada 4 rangka umum yakni Pratt Truss, Howe Truss, Fan Truss, dan Fink Truss. Dengan syarat jarak antar simpul yang digunakan adalah 1,4 m. Di bawah ini adalah gambar dari masing-masing tipe kuda-kuda, seperti pada Gambar 2.
Berdasarkan hasil analisis yang telah dilakukan didapatkan nilai berat, lendutan, dan rasio. Rasio yang paling baik dari perbandingan rangka ini adalah ketika rasio antara lendutan dan berat rangka kuda-kuda memiliki nilai yang paling kecil. Dengan nilai rasio yang kecil menunjukkan kuda-kuda tersebut kuat dan ekonomis. Hasil dari analisis 4 rangka dasar seperti pada tabel 1 sebagai berikut: 


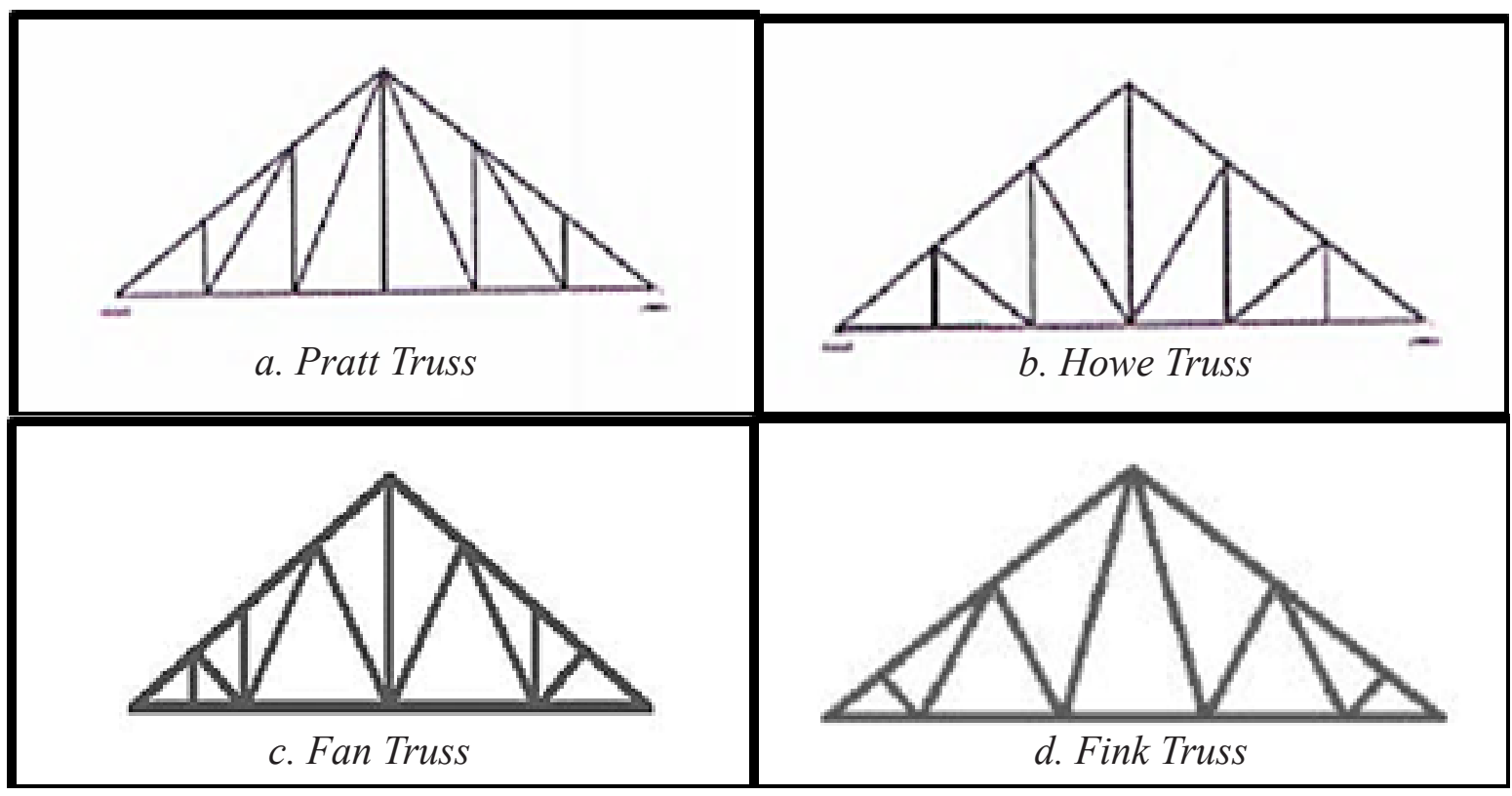

Gambar 2. Tipe-Tipe Kuda-Kuda

Tabel 1. Hasil Pemodelan Kuda-Kuda 4 Rangka Dasar

\begin{tabular}{cccc}
\hline $\begin{array}{c}\text { Bentuk } \\
\text { Kuda- } \\
\text { kuda }\end{array}$ & $\begin{array}{c}\text { Berat } \\
(\mathbf{k g})\end{array}$ & $\begin{array}{c}\text { Lendutan } \\
(\mathbf{m})\end{array}$ & $\begin{array}{c}\text { Rasio } \\
(\mathbf{k g} . \mathbf{m})\end{array}$ \\
\hline Pratt & 56.25 & 0.01615 & 0.9086 \\
\hline Howe & 51.66 & 0.01604 & 0.8288 \\
\hline Fan & 58 & 0.01697 & 0.9843 \\
\hline Fink & 52.44 & 0.01523 & 0.7988 \\
\hline
\end{tabular}

Dari Tabel 1 di atas didapatkan hasil pada bentuk fink dengan berat $52,44 \mathrm{~kg}$, lendutan sebesar $0.01523 \mathrm{~mm}$ dan dengan rasio sebesar 0.7988. Nilai Rasio tersebutlebih kecil dari nilai rasio yang pada jenis rangka-rangka yang lain.

\subsection{Hasil Analisis Modifikasi Rangka}

Pemodelan yang kedua yaitu pemodelan modifikasi rangka. Proses modifikasi kudakuda ini mengacu pada hasil perhitungan dari 4 rangka secara umum yang telah dilakukan. Dan hasilnya adalah terpilih rangka Fink (lihat Tabel 1) yang nantinya akan dimodifikasi dengan cara menambahkan batang horizontal atau penjepit pada arah memanjang kuda-kuda yang ditempatkan pada simpul atas kuda-ku- da. Berikut adalah modifikasi rangka-rangka Fink seperti pada Gambar 3, 4, dan 5 berikut:

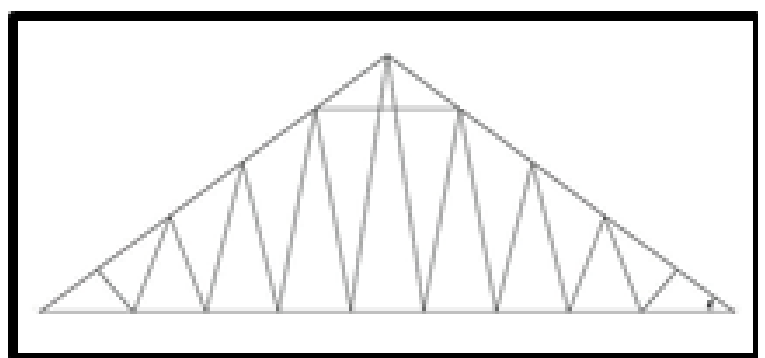

Gambar 3. Modifikasi rangka F1

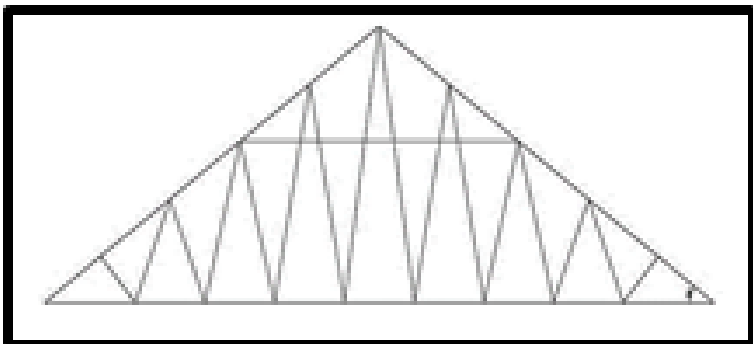

Gambar 4. Modifikasi rangka F2

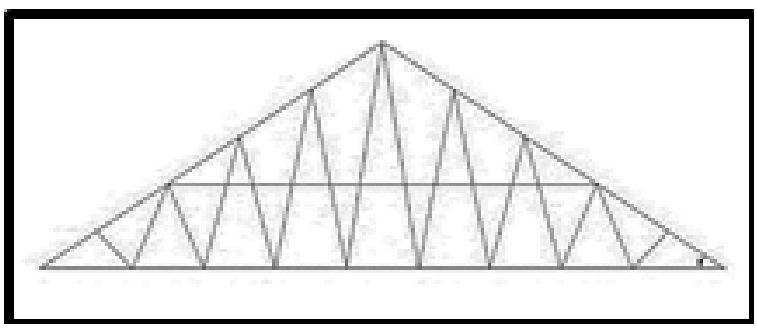

Gambar 5. Modifikasi rangka F3 
Berdasarkan gambar 3, 4, dan 5 di sebelumnya, didapatkan hasil analisis modifikasi rangka sebagai berikut dengan nilai berat, lendutan dan rasio seperti pada tabel 2 di bawah ini:

Tabel 2. Hasil Modifikasi Rangka Fink Truss

\begin{tabular}{cccc}
\hline \multicolumn{4}{c}{ Modifikasi Rangka Fink } \\
\hline Bentuk & $\begin{array}{c}\text { Berat } \\
\text { (kg) }\end{array}$ & $\begin{array}{c}\text { Lendutan } \\
\text { (m) }\end{array}$ & $\begin{array}{c}\text { Rasio } \\
\text { (kg.m) }\end{array}$ \\
\hline F1 & 54.38 & 0.01338 & 0.7275 \\
\hline F2 & 56.33 & 0.01293 & 0.7284 \\
\hline F3 & 58.27 & 0.01367 & 0.7965 \\
\hline
\end{tabular}

Dari tabel 2 di atas didapatkan hasil dengan nilai rasio terkecil pada bentuk rangka tipe F1 dengan nilai berat yakni sebesar $54.38 \mathrm{~kg}$, lendutan sebesar 0.01338 $\mathrm{m}$ dan dengan rasio sebesar 0.7275 .

\subsection{Hasil Analisis Kombinasi Rangka}

Pemodelan ketiga yaitu pemodelan kombinasi rangka. Proses kombinasi rangka ini mengacu pada bentuk modifikasi dengan rasio terkecil yaitu pada Tabel 2 yaitu pada tipe F1, yang nantinya akan dikombinasikan dengan rangka Howe Truss, dan Pratt Truss, Berikut adalah gambar dari masing-masing kombinasi ditunjukkan pada Gambar 6 di bawah ini :

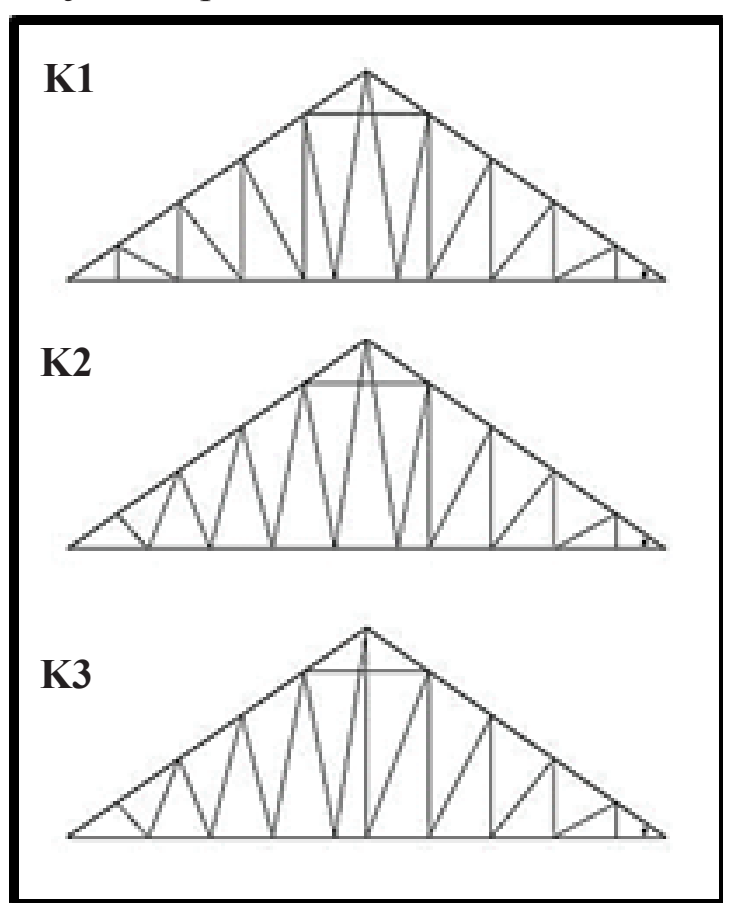

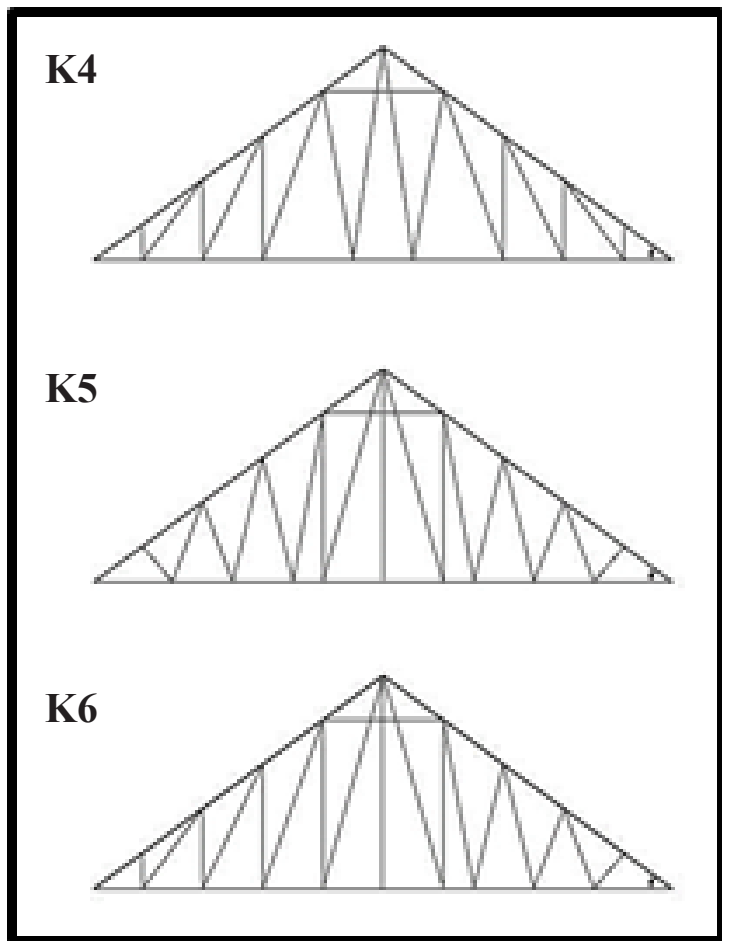

Gambar 6. Kombinasi Rangka Terpilih

Berdasarkan Gambar 6 di atas, didapatkan kombinasirangkaterpilihdengannilaiberat,lendutan dan rasio seperti pada tabel 3 di bawah ini :

Tabel 3. Hasil Lendutan Kombinasi Rangka

\begin{tabular}{cccc}
\hline \multicolumn{4}{c}{ Kombinasi Rangka Terpilih } \\
\hline Bentuk & Berat (kg) & $\begin{array}{c}\text { Lendutan } \\
(\mathbf{m})\end{array}$ & $\begin{array}{c}\text { Rasio } \\
\text { (kg.m) }\end{array}$ \\
\hline K1 & 56.68 & 0.01366 & 0.77415 \\
\hline K2 & 55.53 & 0.01359 & 0.75483 \\
\hline K3 & 55.63 & 0.01361 & 0.75711 \\
\hline K4 & 54.8 & 0.01372 & 0.75163 \\
\hline K5 & 57.77 & 0.01352 & 0.78123 \\
\hline K6 & 57.98 & 0.01404 & 0.8142 \\
\hline
\end{tabular}

Dari tabel 3 di atas didapatkan hasil pada bentuk K4 nilai optimum pada proses kombinasi, dengan nilai berat sebesar $54.80 \mathrm{~kg}$, nilai lendutan sebesar $0.01372 \mathrm{~m}$, dan dengan rasio sebesar 0.75163 . Tetapi nilai rasio tersebut lebih besar daripada nilai rasio pada tabel 2 yang ada pada bentuk modifkasi F1 dengan nilai rasio sebesar 0.7275 , sehingga kombinasi rangka tidak digunakan dikarenakan nilai terkecil dari 
hasil kombinasi lebih besar dari nilai modifikasi rangka yang memiliki hasil lebih optimum.

\section{Hasil Lendutan Maksimum Secara Anal itis dan Uji Prototipe}

\subsection{Hasil Lendutan Analitis Kuda-Kuda}

Hasil dari Pemodelan secara analisis didapatkan bentuk rangka seperti pada gambar 3. Rangka optimum selanjutnya dilakukan uji pembebanan yang diawali dengan beban $50 \mathrm{~kg}$, $100 \mathrm{~kg}$, dan seterusnya hingga kuda-kuda hendak mengalami keruntuhan. Beban maksimum dari pemodelan analitis adalah sebesar 2250 $\mathrm{kg}$ atau setara dengan 2.25 ton dengan lendutan sebesar $11.17 \mathrm{~mm}$. Berikut adalah grafik hubungan beban - lendutan dari pemodelan analitis seperti pada Gambar 7 di bawah ini :

\subsection{Hasil Lendutan Pengujian Protitipe Ku da-Kuda}

Hasil dari lendutan pada pengujian prototipe kuda-kuda sesuai dengan prosedur yang ada dengan interval penambahan $50 \mathrm{~kg}$, didapatkan beban maksimum yang terjadi pada pengujian prototipe kuda-kuda sebesar $1270,99 \mathrm{~kg}$ dengan lendutan sebesar $11.33 \mathrm{~mm}$. Setelah beban maksimum terjadi, kuda-kuda sudah mengalami tanda-tanda keruntuhan, ditandai dengan perubahan bentuk pada kudakuda. Di bawah ini pada Gambar 8 merupakan grafik hubungan beban - lendutan prototipe

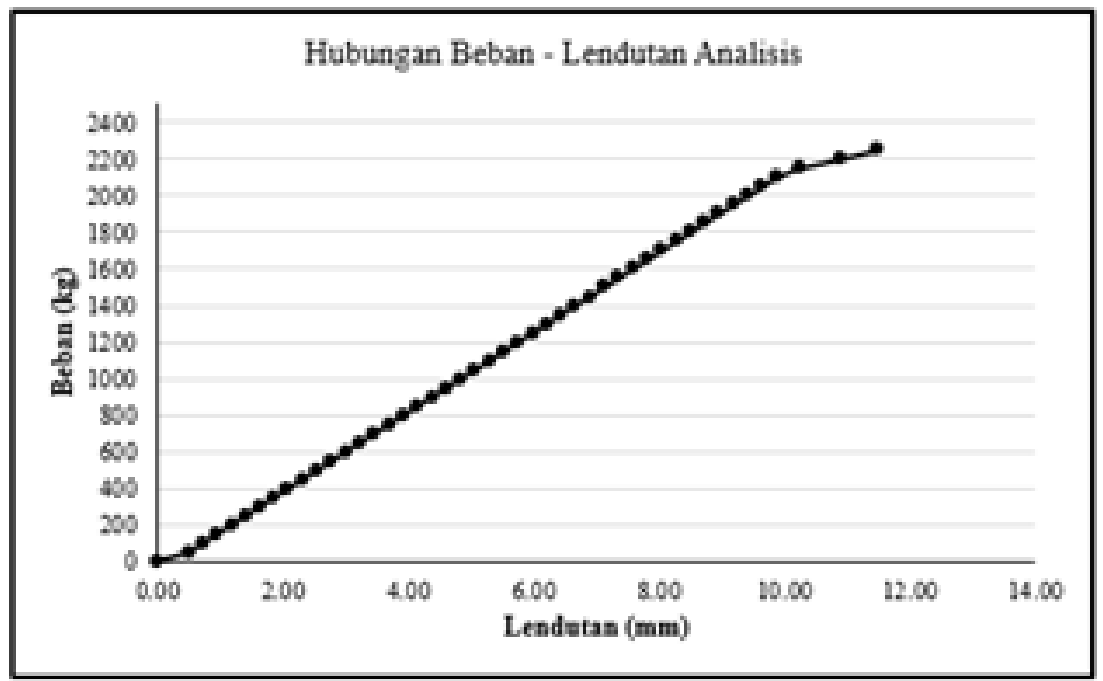

Gambar 7. Grafik Hubungan Beban - Lendutan Analisis

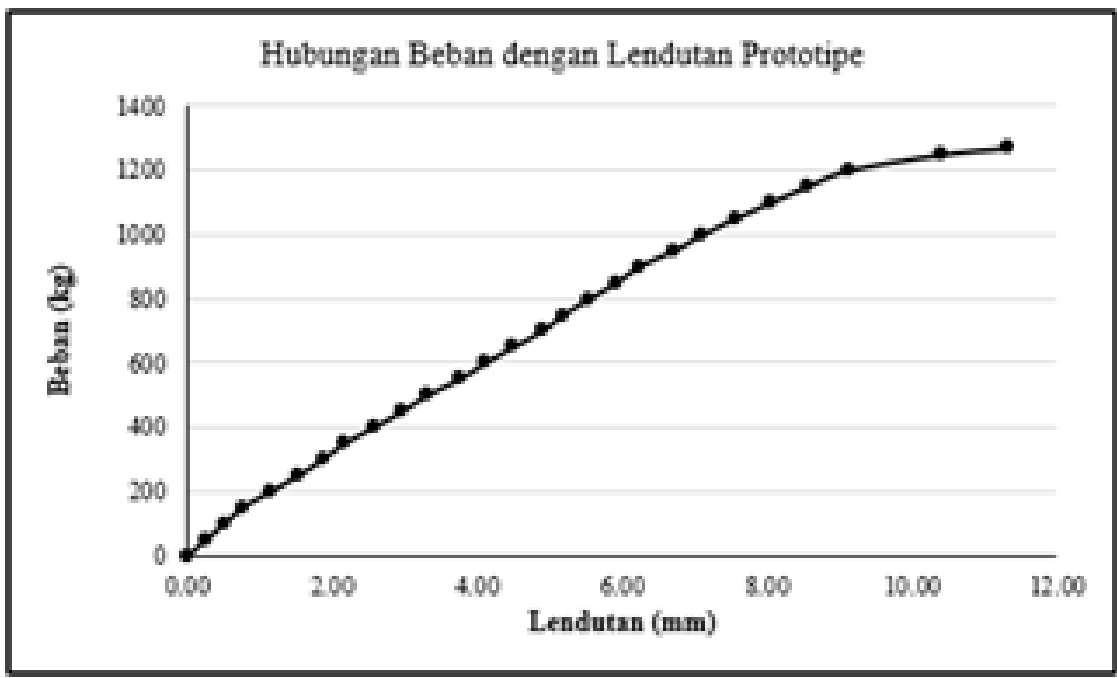

Gambar 8. Grafik Hubungan Beban - Lendutan Prototipe 


\section{Pola Keruntuhan yang Terjadi pada Ku da-Kuda}

Berdasarkan hasil analisis prediksi kerusakan yang terjadi pada daerah tumpuan. prediksi tumpuan ini ditunjukkan pada Gambar 9 berupa output kontur tegangan pada pemodelan analisis, dimana $\mathrm{Y}$ adalah batang tarik, $-\mathrm{Y}$ adalah batang tekan seperti gambar 9 berikut.

Prediksi analisis kerusakan yang terjadi yakni pada daerah tumpuan ditunjukkan dengan notasi -Y7 pada gambar 8 . Semakin besar nilai notasi maka nilai dari tegangan semakin besar. Notasi -Y7 dalam pemodelan tersebut menunjukkan batang mempunyai te- gangan pada batang tekan yang paling besar diantara batang-batang yang lain. Kerusakan yang terjadi pada saat dan setelah pengujian akan dibagi pada tiap bentangnya, yaitu pada daerah tumpuan, daerah $1 / 2$ bentang, dan daerah $1 / 4$ bentangnya. Kerusakan pada daerah tumpuan berupa tekuk lentur torsional. Pada daerah $1 / 2$ bentangnya berupa tekuk torsi, dan pada daerah $1 / 4$ bentangnya berupa terkuk torsi. Berikut akan ditunjukkan Gambar dari pola keruntuhan pada setiap pada kudakuda yang akan ditunjukkan pada gambar 10 berupa kerusakan kuda-kuda sebagai berikut:

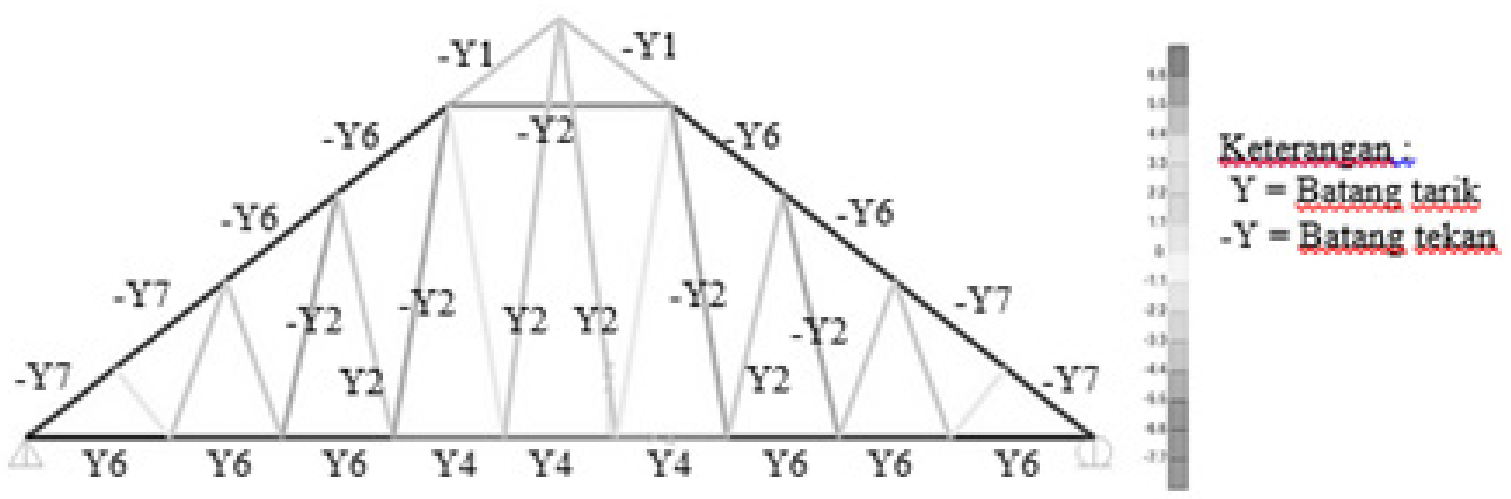

Gambar 9. Output Kontur Tegangan Pemodelan Analisis

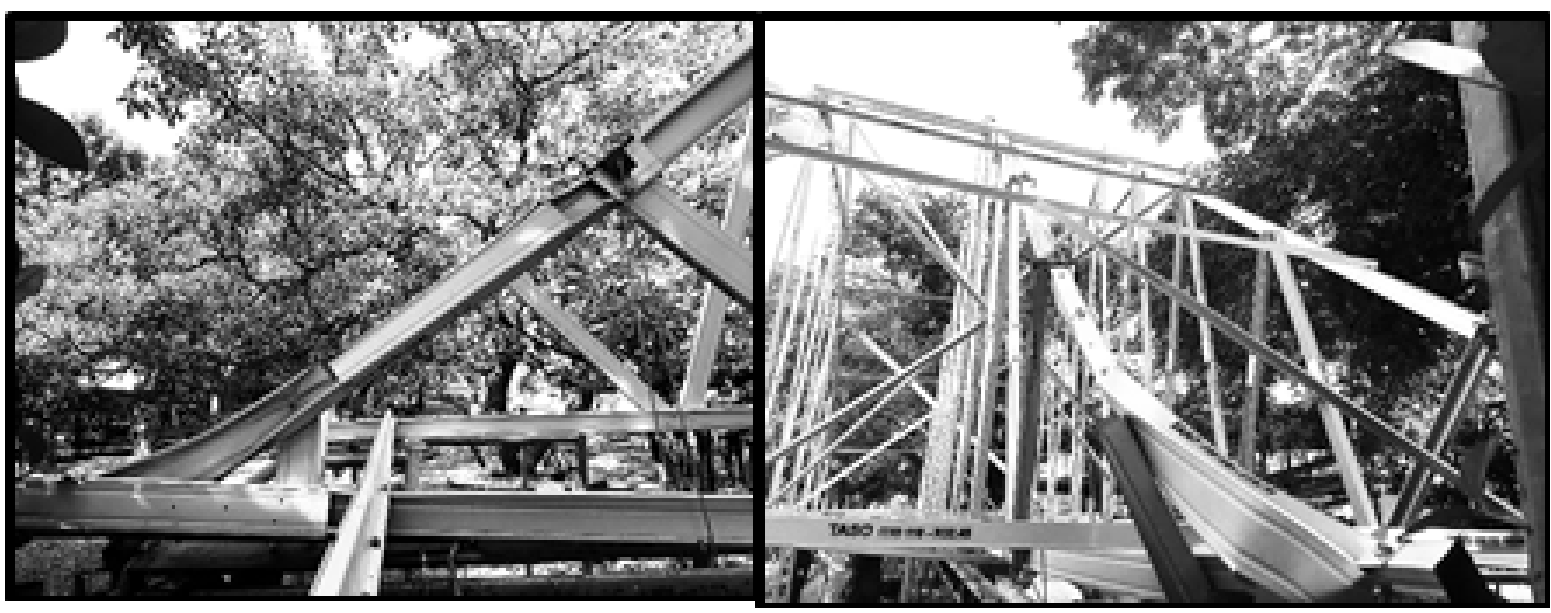

Gambar 10. Kerusakan pada Kuda-Kuda 


\section{PEMBAHASAN}

\section{Optimasi Pemilihan Bentuk Rangka Ku da-Kuda Baja Canai Dingin}

Proses pemilihan rangka dimulai dengan cara mencari rasio terkecil dari masing-masing bentuk kuda-kuda. Dimulai pada bentuk dasar kuda-kuda yakni Pratt Truss, Howe Truss, Fan Truss dan Fink Truss. Dalam proses pencarian bentuk rangka dasar secara analisis didapatkan nilai optimum dengan syarat jarak antar simpul kuda-kuda $1.4 \mathrm{~m}$. Menurut Pujiyanti (2018) panjang efektif baja ringan terhadap gaya tekan untuk profil $\mathrm{C}$ adalah $1400 \mathrm{~mm}$. maka ditemukan hasil untuk bentuk dasar yaitu rangka Fink Truss sebagai rangka dengan nilai rasio terkecil dari rangka yang lain sebesar 0.7988. Selanjutnya dilakukan proses modifikasi pada rangka fink dengan cara menambahkan batang horizontal pada kuda-kuda baja canai. Dan ditemukan pada proses analisis yaitu tipe rangka $\mathrm{F} 1$ dengan nilai rasio terkecil 0.7275. Pada proses kombinasi ini dilakukan dengan mengkombinasikan antara bentuk F1 pada proses modifikasi dengan rangka Pratt Truss, dan Howe Truss. Untuk nilai rasio terkecil dari proses kombinasi didapatkan rangka dengan bentuk K4 yakni sebesar 0.75163 . Jika dibandingkan nilai rasionya antara proses modifikasi dan kombinasi, nilai rasio terkecil didapatkan pada proses modifikasi sebesar 0.7275 sedangkan untuk kombinasi 0.7516 . Untuk hasil optimum pada proses keseluruhan yang dipakai adalah pada proses modifikasi yakni dengan rangka tipe $\mathrm{F} 1$.

\section{Analisis Lendutan Pemodelan Analisis dan Pemodelan Kuda-Kuda Prototipe}

Hasil dari pemodelan kuda-kuda secara analisis dengan menggunakan software memiliki lendutan maksimal sebesar $11.17 \mathrm{~mm}$ pada beban $2250 \mathrm{~kg}$. Dan pada pengujian pemodelan kuda-kuda prototipe lendutan yang terjadi sebesar $11.33 \mathrm{~mm}$ pada beban 1270 $\mathrm{kg}$. Berikut adalah grafik hubungan bebanlendutan dari pemodelan analitis dan prototipe seperti pada Gambar 11 di bawah ini :

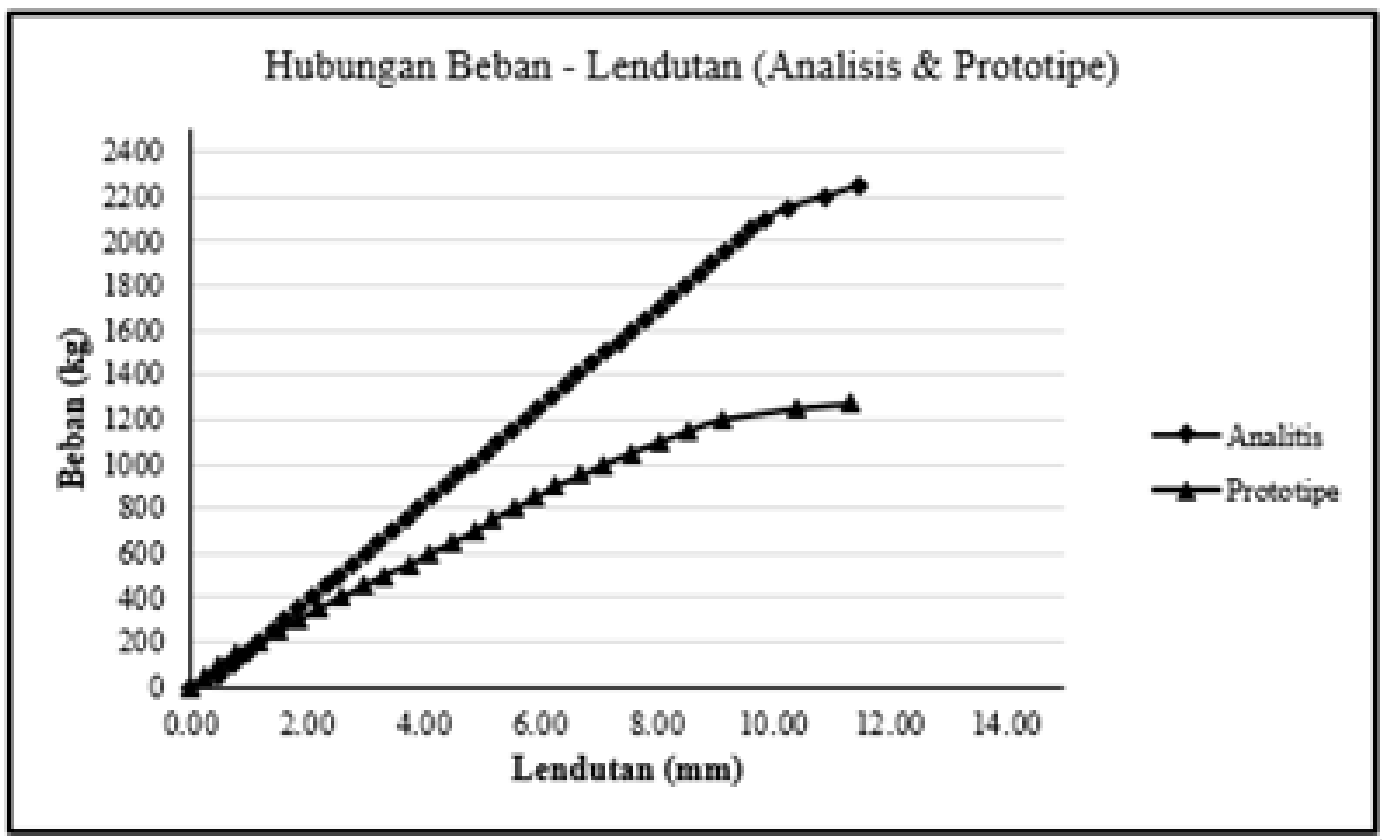

Gambar 11. Grafik Hubungan Beban - Lendutan Analitis dan Prototipe 
Berdasarkan Gambar 11 sebelumnya terjadi perbedaan sebesar $43.54 \%$ antara hasil analisis dengan pengujian Permodelan analisis pada beban 0 sampai $2100 \mathrm{~kg}$ baja canai masih dalam kondisi elastis belum mengalami kondisi plastis. Sedangkan pemodelan prototipe kondisi elastis terjadi pada beban $0 \mathrm{~kg}$ sampai $1050 \mathrm{~kg}$. Kondisi elastis yaitu kondisi dimana suatu material masih bisa kembali ke bentuk semula setelah diberikan perlakuan pada material tersebut. Pada beban 1100 kg pemodelan kuda-kuda sudah memasuki kondisi plastis, sedangkan pada pemodelan analisis pada beban $2150 \mathrm{~kg}$. Kondisi plastis yaitu kondisi dimana material tidak mampu kembali pada bentuk semula atau sudah mengalami perubahan bentuk pada materialnya.

Adanya perbedaan hasil dari pemodelan kuda-kuda secara analisis dan pemodelan kuda-kuda prototipe atau kuda-kuda sebenarnya, maka dibuatnya angka keamanan untuk meminimalisir terjadinya ketidaksesuaian hasil. Dari persamaan 1 maka dapat dihitung perkiraan angka keamanan dari hasil beban uji analisis dan hasil uji beban kuda-kuda prototipe berikut :

$$
M S=1+\frac{43.54 \%}{100 \%}
$$

$M s=1.435 \cong 1.40$

Dari perhitungan di atas, diperoleh angka keamanan yang disarankan yaitu sebesar 1,4. Jika dihubungkan dengan SNI-1727-2013 tentang "Beban minimum untuk perancangan bangunan gedung dan struktur lain" beban berfaktor adalah kekuatan struktur yang dibutuhkan dalam menampung beban yang bekerja pada suatu struktur. Suatu struktur harus direncanakan untuk memiliki cadangan kekuatan untuk menutupi beban-beban yang tidak direncanakan dan ditambah beban tak terdu- ga. Untuk itu fungsi direkomendasikan faktor keamanan untuk menutupi hal-hal tersebut.

\section{Analisis Pola Keruntuhan Prototipe Ku da-Kuda}

Pada pengujian kuda-kuda yang telah dilakukan dengan rangka tipe modifikasi F1, deformasi pada darah tumpuan berupa tekuk lentur torsional. Tekuk lentur torsi adalah tekuk dimana terjadinya akibat batang terpelintir terhadap sumbu sejajar dengan beban, baja canai melentur dan memutar. Hal ini terjadi akibat pemasangan yang tidak sejajar atau tidak simetris atau bisa juga saat pembebanan, beban yang tersalur tidak merata sehingga terjadi tekuk lentur torsi.

Kerusakan yang terjadi pada daerah $1 / 2$ bentang berupa tekuk torsi. Tekuk torsi terjadi akibat batang terpelintir terhadap sumbu yang sejajar dengan beban. Batang canai dingin meleyot ke dalam kearah dimana ikatan angin berada. Menurut Herwahyuangka (2019) semakin banyak jumlah pengaku lateral akan menambah panjang efektif namun akan mengurangi kapasitas tekan pada batang profil C. Sehingga penambahan 3 pengaku pada batang tekan sangat efektif meminimalisir terjadinya kerusakan yang berat pada daerah $1 / 2$ bentang. Sedangkan pada daerah sambungan tidak terjadi dan tidak tampak kerusakan yang berarti.

Kerusakan yang terjadi pada daerah 1/4 bentang juga berupa tekuk torsi. Batang tertekan dan terpelintir kearah dimana ikatan angin berada. Pada bagian ikatan angin sambungan mengalami kerusakan berupa lepasnya baut (screw) pada batang diagonal, hal ini terjadi akibat batang tidak mampu menahan beban sehingga mengakibatkan terlepasnya sambugan pada ikatan angin. Sedangkan pada sambungan antar batang send- 
iri tidak mengalami kerusakan yang berarti.

\section{SIMPULAN}

Berdasarkan hasil penlitian yang telah dilakukan melalui pemodelan secara analisis maupun pemodelan prototipe kuda-kuda bentuk dari suatu rangka kuda-kuda baja canai dingin masih bisa untuk dioptimalkan. Berdasarkan hasil pemodelan secara analisis dari beberapa tahap bentuk dari rangka kuda-kuda baja canai yang ditemukan, yakni bentuk rangka Fink yang dimodifikasi dengan batang horizontal dengan tipe F1 pada proses modifikasi. Pada tahap selanjutnya yakni proses kombinasi rangka tidak mencapai bentuk yang optimum.

Lendutan maksimum pada pemodelan secara analisis yakni sebesar $11.17 \mathrm{~mm}$ pada beban $2250 \mathrm{~kg}$. Sedangkan pada pemodelan prototipe lendutan maksimum yang terjadi sebesar $11.33 \mathrm{~mm}$ pada beban $1270.99 \mathrm{~kg}$. Kondisi elastis pada pemodelan analisis terjadi pada beban 0-2100 kg, sedangkan pada pemodelan prototipe kuda-kuda terjadi pada beban $0-1050 \mathrm{~kg}$. Kondisi plastis pada analisis terjadi pada beban di atas beban 2100 atau dimulai pada beban $2150 \mathrm{~kg}$, sedangkan pada pengujian terjadi pada beban $1100 \mathrm{~kg}$. Terjadi perbedaan sebesar $43.54 \%$ antara pemodelan analisis dan pengujian prototipe kuda-kuda. Faktor-faktor yang menyebabkan terjadinya perbedaan yaitu sambungan antar batang jika pada pemodelan analisis yang terjadi yakni sambungan sempurna dan tiap simpul sentris, sedangkan pada pengujian sambungan yang digunakan belum sepenuhnya sendi dan sambungan antar bataang non sentris.

Berdasarkan hasil analisis secara analisis dan hasil pemodelan kuda-kuda prototipe, terjadi perbedaan hasil. Untuk meminimalisir perbedaan hasil disarankan menggunakan an- gka keamanan yang direkomendasikan sebesar 1,4. Angka tersebut tidak bersifat mutlak, namun untuk keamanan perencanaan angka tersebut dapat digunakan. Berdasarkan hasil analisis, prediksi kerusakan yang terjadi pada pengujian yakni pada daerah tumpuan berupa tekuk lentur. Pola keruntuhan yang terjadi dalam pengujian (model), pada 1/2, $1 / 4$ bentang terjadi tekuk torsi, dan pada bagian tumpuan terjadi tekuk lentur torsional.

\section{DAFTAR RUJUKAN}

Alpine, 2010. Encyclopedia of Trusses. Unit ed States, Canada (8-9)

Effendi. A., Sulistyorini. D., Candra.G.L. Dimas., 2017. Analisis Perbandingan $\mathrm{Ku}$ da-Kuda Baja Ringan dengan Beton Ber tulang menggunakan Program SAP2000 v.18. Yogyakarta.

Herman. H., Fitrah. A. Ridho., Haris. Sabril. 2018. Studi Optimalisasi Konfigurasi Struktur Kuda-Kuda Atap Baja Ringan. Ju rnal Rab Construction Research. Vol. 3, No. 1

Herwahyuangka, L. 2019. Penentuan Panjang Efektif Profil Baja Canai Dingin den gan Pengaku Lateral Terhadap Gaya Tekan. Malang : Univeristas Negeri Malang. Skripsi

Husada. G, Christie. M . 2012 . Pengaruh Penambahan Beban Pada Rangka Atap Ter hadap Lendutan.

Pangaribuan, M.R. 2014. Baja Ringan Seb agai Pengganti Kayu Dalam Pembuatan Rangka Atap Bangunan Rumah Masyara kat. Jurnal Teknik Sipil dan Lingkungan. Vol. 2 , No. 4

Peraturan Pembebanan Indonesia untuk Ge dung (1983) (PPIUG)

Pujiyanti. Y. R. 2018, Penentuan Panjang 
Efektif Profil Baja Ringan (Canai Dingin)

Terhadap Gaya Tekan. Malang : Universi tas Negeri Malang. Skripsi.

Rahayu. A. Sherly., Manalu. F. Donny., 2015. Analisis Perbandingan Rangka Atap Baja Ringan dengan Rangka Atap Kayu Terha dap Mutu, Biaya dan Waktu. Jurnal Fropil. Vol 3, No. 2.

Sanjdaya. A., Suryoatmono. B. 2018. Studi Eksperimental Batang Tekan Baja Canai Dingin Diperkaku Sebagian. Jurnal Teknik Sipil, Vol 25 No 1

Standar Nasional Indonesia. 1727 : 2013. Per aturan Pembebanan Indonesia untuk Ge dung dan Bangunan Lain. Jakarta : Badan Standarisasi Nasional

Standar Nasional Indonesia. 1726 : 2012. Tata Cara Perencanaan Ketahanan Gempa Un tuk Struktur Bangunan Gedung dan Non gedung. Jakarta : Badan Standarisasi Nasi onal

Sucipta. A., Saggaf. A., Muliawan. S., 2013. Analisis Pola Keruntuhan Konstruksi Rangka Atap dengan Menggunakan Profil Baja Ringan. Jurnal Teknik Sipil dan Ling kungan. Vol 1, No. 1 
20 JURNAL BANGUNAN, VOL. 25, NO.1, MARET 2020: 9-20 